\title{
Bovine trypanosomosis and its fly vectors in three selected settlement areas of Hawa-Gelan district, western Ethiopia
}

\author{
Authors: \\ Kumela Lelisa ${ }^{1}$ \\ Shihun Shimeles ${ }^{1}$ \\ Jemere Bekele ${ }^{2}$ \\ Desie Sheferaw ${ }^{2}$ \\ Affiliations: \\ ${ }^{1}$ College of Veterinary \\ Medicine, Haramaya \\ University, Ethiopia \\ ${ }^{2}$ School of Veterinary \\ Medicine, Hawassa \\ University, Ethiopia \\ Correspondence to: \\ Desie Sheferaw \\ Email: \\ mereba480@gmail.com \\ Postal address: \\ PO Box 05, Hawassa, Ethiopia \\ Dates: \\ Received: 30 Nov. 2013 \\ Accepted: 09 June 2014 \\ Published: 12 Nov. 2014 \\ How to cite this article: \\ Lelisa, K., Shimeles, S., \\ Bekele, J. \& Sheferaw, \\ D., 2014, 'Bovine \\ trypanosomosis and its fly \\ vectors in three selected \\ settlement areas of Hawa- \\ Gelan district, western \\ Ethiopia', Onderstepoort \\ Journal of Veterinary \\ Research 81(1), Art. \#715, \\ 5 pages. http://dx.doi. \\ org/10.4102/ojvr.v81i1.715 \\ Copyright: \\ C 2014. The Authors. \\ Licensee: AOSIS \\ OpenJournals. This work \\ is licensed under the \\ Creative Commons \\ Attribution License.
}

Read online:
A cross-sectional study aimed at investigating the species diversity of fly vectors and estimating the prevalence of bovine trypanosomosis was carried out from October 2009 to May 2010 in selected settlement areas of the Hawa-Gelan district in the western Wollega zone of Ethiopia. Standard methods of sampling and identification were employed for both entomological and parasitological examination. Three species of the genus Glossina (Glossina pallidipes, Glossina morsitans submorsitans and Glossina fuscipes) and two genera of biting flies (Stomoxys and Tabanus) were caught and identified. The overall apparent density of Glossina species caught was 10.5 flies per trap per day, with a higher proportion of female flies (57.2\%). Out of a total 389 cattle examined, 42 (10.8\%; $95 \%$ CI: $7.89 \%-14.3 \%$ ) were found infected with trypanosomes. Three trypanosome species were detected in the study area, namely Trypanosoma congolense (54.8\%), Trypanosoma brucei (23.8\%) and Trypanosoma vivax (21.4\%). The prevalence of trypanosomosis was found to be significantly $(p<$ $0.05)$ higher in cattle with poor body condition. There was an association between mean packed cell volume (PCV) and the occurrence of parasitaemia $\left(\chi^{2}=49.5, p<0.05\right)$. About $95.2 \%$ of cattle that were positive for trypanosomes had a PCV less than the lower limit for cattle. Considering the current result, bovine trypanosomosis seems to be a serious constraint for agricultural activities in the settlement areas of the Hawa-Gelan district and seems to be associated with the presence of Glossina species. Therefore, application of control methods through community involvement to reduce the Glossina species infestation level is likely to increase animal productivity.

\section{Introduction}

Agriculture is the mainstay of the Ethiopian economy. A large part of the agricultural system is not mechanised, so livestock play a crucial role in agricultural production both directly as food sources and as a source of traction power. Trypanosomosis is a major constraint in the health and productivity of livestock and hence agricultural production in Ethiopia in general (Ministry of Agriculture [MOA] 1995). Annual losses to the national economy are estimated to exceed $\$ 200$ million because of mortality and morbidity of livestock, denied access to land resources and the costs of controlling this disease (Taye et al. 2012; Vreysen et al. 1999). Approximately $220000 \mathrm{~km} 2$ of otherwise agriculturally productive land in the western and south-western part of the country (MOA 1995) is estimated to be infested by five different species of tsetse flies (Glossina morsitans submorsitans, Glossina pallidipes, Glossina tachinoides, Glossina fuscipes fuscipes and Glossina longipennis) (Abebe 2005).

Of the species of trypanosomes recorded in Ethiopia, the most important trypanosomes in terms of economic loss in domestic livestock are the tsetse-transmitted species Trypanosoma congolense, Trypanosoma vivax and Trypanosoma brucei (Abebe 2005). About 14.8 million cattle, 6.1 million sheep and goats, 1 million camels and 1.2 million equines live in endemic areas (MOA 1995).

Currently, trypanosomosis is found to be one of the factors hampering livestock production and productivity in most settlement areas of western Ethiopia. An understanding of the prevalence of the disease and magnitude of the vector population is crucial for designing appropriate control strategies. The current study was planned and carried out to fill such gaps. Therefore, the aim of this research was to estimate the prevalence of trypanosomosis in cattle and relative abundance and species of both Glossina and other biting flies responsible for transmitting the disease in selected settlement areas of the Hawa-Gelan district.

\section{Materials and methods}

\section{Study area}

The study was conducted from October 2009 to May 2010 in the Hawa-Gelan district, located in the Birbir valley, in the western Wollega zone of the Oromia region, Ethiopia. The altitude of the areas 
ranges from 1200 m.a.s.l. to 2210 m.a.s.l. and they are located at $08^{\circ} 34^{\prime} \mathrm{N}$ and $35^{\circ} 59^{\prime} \mathrm{E}$. The area is endowed with water bodies like Keto/Hindina, Hokorsa, Lome and Kombolcha and many other tributaries that drain into a large river named the Birbir. According to the Hawa-Gelan District Agricultural Office (2009), the climate of the area varies from humid to sub-humid, with an annual mean temperature of $28.5^{\circ} \mathrm{C}$ and humidity of $55 \%$. The annual rainfall ranges from $700 \mathrm{~mL}$ to $1100 \mathrm{~mL}$. The dominant vegetation types of all the study areas are trees (Acacia jacaranda and Cordia africana), and the dominant trees in the wooded grassland (savannah) are species of Pilostigma. The main crop types cultivated include maize, barley, sorghum, coffee, teff and beans. The settlement areas selected and included in the study were Settlement 17, Tulema and Settlement 21 (Figure 1). The criteria for selection of the three settlement areas were based on their accessibility and nature of the habitat as well as farmers' complaints of the problem.

\section{Study animals and sampling}

The study animals were indigenous breeds of cattle kept under an extensive husbandry system that allows free grazing, usually mixed with other livestock species in selected settlement areas. A cross-sectional study design was followed to estimate the prevalence of trypanosomosis in cattle in the area. Hence, a total of 389 cattle were selected from the study animals by a systematic random sampling technique (see Thrusfield 2005) with a 95\% confidence interval, 5\% desired absolute precision, and 50\% expected prevalence. (As the actual prevalence was unknown, 50\% was used as the corresponding sample size is the largest.) The body condition status of selected animals was assessed and ranked as good, medium and poor (see Nicholson \& Butterworth 1986).

\section{Entomological data}

The density and diversity of Glossina species were assessed using odour-baited biconical traps deployed at $200 \mathrm{~m}$ $250 \mathrm{~m}$ intervals. The odour baits used contained acetone, Octanol and aged cow urine. A total of 71 traps were used; 21,26 and 24 were deployed in the riverside and wooded grassland areas of Settlement 21, Tulema and Settlement 17 respectively. Flies were collected from each trap after $48 \mathrm{~h}$ of deployment and then identified based on their morphology, as described by Uilenberg (1998) and Pollock (1982).

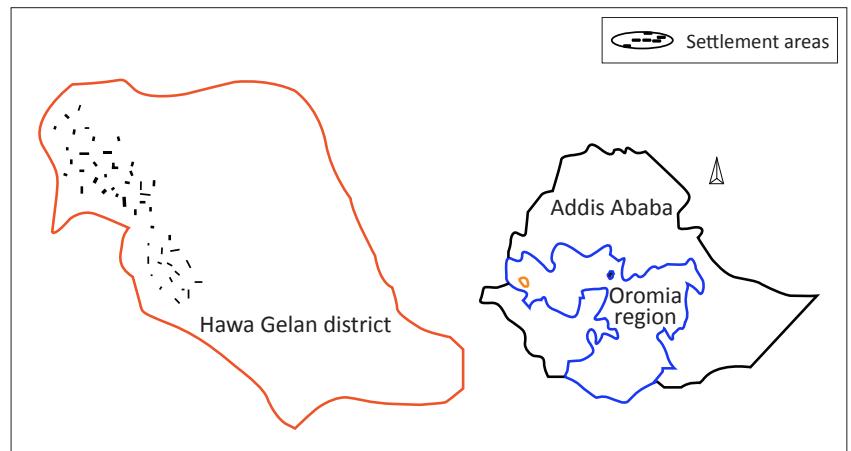

FIGURE 1: Map of the study area, Hawa-Gelan district.

\section{Parasitological and haematological data}

Blood samples were collected from marginal ear veins using a heparinised micro-haematocrit capillary tube which was sealed on one side with Cristaseal (Hawksley Ltd, Lancing, UK). The capillary tube was then transferred to a haematocrit centrifuge and spun for $5 \mathrm{~min}$ at 1200 revolutions per minute. The centrifuged capillary tube was measured on a haematocrit reader to estimate the packed cell volume (PCV) as an indicator of anaemia. It was then cut $1 \mathrm{~mm}$ below the buffy coat (BC) and the contents of the tube expressed onto a slide, mixed and covered with a $22 \mathrm{~mm} \times 22 \mathrm{~mm}$ cover slip. The slide was then examined with a 40x objective lens using phase contrast (Murray et al. 1983; Uilenberg 1998) or dark field microscopy to detect the presence of motile trypanosomes. For the purpose of species identification, a thin blood smear was prepared from the BC for those samples that were positive on $\mathrm{BC}$ examination and stained with Giemsa stain and examined under a microscope using the oil immersion 100x objective lens (Murray et al. 1983).

\section{Data analysis}

All statistical analyses were performed using STATA version 11.0 software (Stata Corp., College Station, USA). The proportion of vector flies (Glossina species and biting flies) caught per trap per day was computed to determine their relative abundance and species diversity. The prevalence of trypanosomosis was computed by dividing the number of infected animals by the total number of samples and multiplying the result by 100 . The prevalence of trypanosome infection between the study variables (such as body condition and settlement areas) was compared by chi-square $\left(\chi^{2}\right)$ test of independence for significance.

\section{Results \\ Entomological results}

Two genera of biting flies, Stomoxys and Tabanus, and three species of Glossina were encountered during the entomological survey. Glossina morsitans submorsitans, G. pallidipes and G. fuscipes were the species of Glossina caught during the period (Figure 2). The relative abundance of Glossina species and other biting flies is shown in Table 1. The overall Glossina species caught per 48 hours in Settlement 21, Tulema and Settlement 17 were 366, 432 and 698, respectively. Fly catch

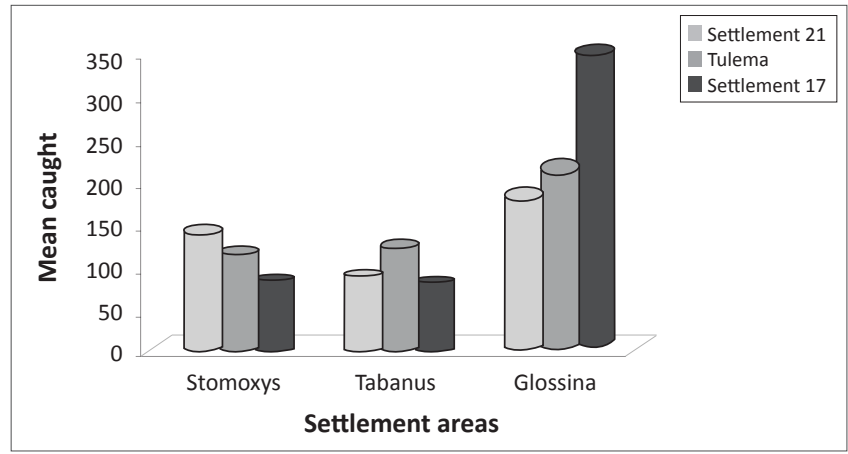

FIGURE 2: Mean catch of fly genera (flies per trap per day) per settlement. 
per trap per day was computed from these values and is shown in brackets. The male and female proportions of each species are shown in Table 2. The male to female ratios of Glossina species were 1:1.4, 1:1.3 and 1:1.2 for G. morsitans submorsitans, G. pallidipes and G. fuscipes, respectively.

\section{Parasitological results}

Out of 389 cattle examined, 42 (10.8\%; 95\% CI: 7.9\% - 14.31\%) were found to be infected with trypanosome species. The proportion of cattle infected in the three settlement areas is shown in Table 3. No significant variation was seen in the infection status between settlement sites $(p>0.05)$.

Of the 42 cattle positive for trypanosomes, 23 (54.8\%), 10 $(23.8 \%)$ and $9(21.4 \%)$ cases were caused by $T$. congolense, $T$. brucei and T. vivax, respectively.

Of the 389 cattle examined, 95 (24.4\%), 122 (31.4\%) and 172 $(44.2 \%)$ were in poor, medium and good body condition, respectively. More than half of the infected cattle (22 out of 42 or $52.4 \%$ ) were those which were ranked as having poor body condition (Table 4 ). Therefore a significant association $(p<0.05)$ is observed between infection and body condition of animals.

\section{Haematological findings}

In this study, a PCV measurement of $25 \%$ and above was considered to be normal (Douglas \& Wardrop 2010). The overall mean PCV of the cattle sampled was $26.6 \%$ (95\% CI: $10 \%-41 \%$ ). The mean PCV of parasitaemic cattle was $17.1 \%$ (95\% CI: $10 \%-28 \%)$. There was a significant association between mean PCV and the occurrence of parasitaemia $\left(\chi^{2}\right.$ $=49.5, p<0.05)$. About $95.2 \%$ of cattle that were positive for trypanosomes had a PCV less than the minimum value for cattle, whereas only $23.3 \%$ of aparasitaemic cattle had less than $25 \%$.

\section{Discussion and conclusions}

In this study, the entomological findings revealed that three species of Glossina out of five reported in Ethiopia (Abebe 2005) and other biting flies (Stomoxys and Tabanus species) occur in the selected settlement areas of the Hawa-Gelan district. The three species of Glossina (G. pallidipes, G. morsitans submorsitans and G. fuscipes) have also been reported in the western and south-western parts of the country (Daya \& Abebe 2008; Desta, Menkir \& Kebede 2013). The overall apparent density of Glossina species was 10.5 flies per trap per day. The apparent densities of Glossina species were 8.6,

TABLE 1: Relative abundance of Glossina species and biting flies trapped from three settlement areas.

\begin{tabular}{|c|c|c|c|c|c|c|c|c|c|c|c|c|c|c|}
\hline \multirow[t]{3}{*}{ Area } & \multirow{3}{*}{$\begin{array}{l}\text { Altitude } \\
\text { range }\end{array}$} & \multirow{3}{*}{$\begin{array}{l}\text { Number } \\
\text { of traps }\end{array}$} & \multicolumn{8}{|c|}{ Glossina species and F/T/D } & \multirow{2}{*}{\multicolumn{2}{|c|}{$\begin{array}{c}\text { Stomoxys } \\
\text { specie (F/T/D) }\end{array}$}} & \multirow{2}{*}{\multicolumn{2}{|c|}{$\begin{array}{l}\text { Tabanus } \\
\text { (F/T/D) }\end{array}$}} \\
\hline & & & \multicolumn{2}{|c|}{ Gp } & \multicolumn{2}{|c|}{$\mathrm{Gm}$} & \multicolumn{2}{|c|}{ Gf } & \multicolumn{2}{|c|}{ Overall (F/T/D) } & & & & \\
\hline & & & $n$ & $\%$ & $n$ & $\%$ & $n$ & $\%$ & $n$ & $\%$ & $n$ & $\%$ & $n$ & $\%$ \\
\hline Settlement 21 & $1312-1319$ & 21 & 189 & 4.5 & 173 & 4.1 & - & - & 362 & 8.6 & 273 & 6.5 & 164 & 3.9 \\
\hline Tulema & $1300-1380$ & 26 & 194 & 3.7 & 238 & 4.6 & - & - & 432 & 8.3 & 228 & 4.4 & 238 & 4.6 \\
\hline Settlement 17 & $1400-1500$ & 24 & 318 & 6.6 & 217 & 4.5 & 163 & 3.4 & 698 & 14.5 & 159 & 3.3 & 154 & 3.2 \\
\hline Total & - & 71 & 701 & 4.9 & 628 & 4.4 & 163 & 1.2 & 1492 & 10.5 & 660 & 4.6 & 556 & 3.9 \\
\hline
\end{tabular}

F/T/D, flies per trap per day; Gp, Glossina pallidipes; Gm, Glossina morsitans submorsitans; Gf, Glossina fuscipes.

TABLE 2: Proportion of male and female Glossina species.

\begin{tabular}{|c|c|c|c|c|c|c|c|}
\hline \multirow[t]{3}{*}{ Settlement area } & \multirow{3}{*}{$\begin{array}{l}\text { Glossina caught } \\
\text { overall }\end{array}$} & \multicolumn{6}{|c|}{ Proportion of Glossina species } \\
\hline & & \multicolumn{2}{|c|}{ Glossina morsitans submorsitans } & \multicolumn{2}{|c|}{ Glossina pallidipes } & \multicolumn{2}{|c|}{ Glossina fuscipes } \\
\hline & & Male $(\%)$ & Female (\%) & Male (\%) & Female (\%) & Male $(\%)$ & Female (\%) \\
\hline Settlement 21 & 362 & 39.3 & 60.1 & 43.9 & 57.1 & - & - \\
\hline Tulema & 432 & 42.0 & 58.0 & 47.9 & 52.1 & - & - \\
\hline Settlement 17 & 698 & 43.3 & 56.7 & 40.6 & 59.4 & 44.8 & 55.2 \\
\hline Total & 1492 & 41.9 & 58.1 & 43.2 & 56.8 & 44.8 & 55.2 \\
\hline
\end{tabular}

TABLE 3: Occurrence of trypanosome infection in cattle in settlement areas of Hawa-Gelan district.

\begin{tabular}{|c|c|c|c|c|c|c|}
\hline \multirow[t]{2}{*}{ Settlement area } & \multirow[t]{2}{*}{ Number examined } & \multicolumn{2}{|c|}{ Prevalence number } & \multirow[t]{2}{*}{$95 \% \mathrm{Cl}$} & \multirow[t]{2}{*}{$\chi^{2}$} & \multirow[t]{2}{*}{$p$-value } \\
\hline & & $n$ & $\%$ & & & \\
\hline Settlement 21 & 126 & 14 & 11.1 & $5.6-16.6$ & - & - \\
\hline Tulema & 165 & 16 & 9.7 & $5.2-14.2$ & - & - \\
\hline Settlement 17 & 98 & 12 & 12.2 & $5.7-18.8$ & 0.43 & 0.805 \\
\hline
\end{tabular}

TABLE 4: Relationship between infection and body condition of cattle.

\begin{tabular}{|c|c|c|c|c|c|}
\hline \multirow[t]{2}{*}{ Body Condition } & \multicolumn{2}{|c|}{ Number of animals } & \multirow[t]{2}{*}{ Prevalence(\%) } & \multirow[t]{2}{*}{$\chi^{2}$-value } & \multirow[t]{2}{*}{$p$-value } \\
\hline & Examined & Positive & & & \\
\hline Good & 172 & 8 & 4.7 & & \\
\hline Medium & 122 & 12 & 8.8 & 21.9 & 0.00 \\
\hline Poor & 95 & 22 & 23.2 & & \\
\hline Total & 389 & 42 & 10.8 & - & - \\
\hline
\end{tabular}


8.3 and 14.5 flies per trap per day in Settlement 21, Tulema and Settlement 17, respectively. In the western part of the country, various reports indicate that the apparent density of Glossina species ranges from 0.3 to 24.4 flies per trap per day (Desta et al. 2013; Regassa \& Abebe 2009; Rundassa, Menkir \& Kebede 2013; Tilahun et al. 1999). This wider range is accounted for by differences in season and density of vegetation cover. The riverine vegetation and savannah habitats prevailing in the areas are very important for the widespread occurrence of Glossina species (Desta et al. 2013). According to Leak (1999), vegetation is vital for providing suitable conditions. Glossina pallidipes is widespread in the bush vegetation type (Bancha 2001).

There was no significant variation between Settlement 21 and Tulema, which could be attributed to similarities in ecological situations characterised by bushes and grassland. However, there was a significant difference between Settlement 17 and the other two sites, which could be attributed to the difference in habitat for Glossina species. Settlement 17 is characterised by dense forest cover in addition to the grassland and bush coverage. Bancha (2001) also reported the highest total catch from the bush vegetation type. A higher proportion of female Glossina species (57.2\%) was caught than male $(42.8 \%)$, which is in line with various reports from the country (Bancha 2001; Daya \& Abebe 2008; Desta et al. 2013). This could be attributed to the longer lifespan of female compared to male Glossina (Leak 1999).

Furthermore, a $10.8 \%$ overall prevalence of cattle trypanosomosis was detected in this study. This finding is generally in agreement with reports of studies carried out in the western part of Oromia State and the northern part of the Southern Nations, Nationalities and Peoples' Region (SNNPR), Ethiopia (Asha et al. 2008; Bogale, Wodajo \& Chanie 2012; Daya \& Abebe 2008; Rundassa et al. 2013; Tasew \& Duguma 2012). The occurrence of trypanosome infections in cattle is clearly linked to the presence of potential fly vectors (Glossina species and other biting flies) in the study areas. The study was carried out in the late rainy and dry seasons of the year and therefore there was no significant difference in the prevalence of cattle trypanosomosis amongst the three settlement areas. This reflects the presence of continued Glossina challenge to cattle as the animals are driven to pasture and water sources, where they congregate. In this study three species of trypanosomes were identified, namely $T$. congolense, $T$. vivax and $T$. brucei, in the ratio 2.6:1:1.1. These species are widespread in most parts of western Ethiopia (Abebe 2005; Mulaw, Addis \& Fromisa 2011), and T. congolense was found to be the most prevalent when compared to other species. This finding is in agreement with various reports from the western part of the country (Abebe \& Jobre 1996; Bekele et al. 2010; Mulaw et al. 2011; Rundassa et al. 2013).

This study also demonstrated an association between the body condition of cattle and the occurrence of trypanosome infections. This could be explained by the occurrence of infections in $52.4 \%, 28.6 \%$ and $19.0 \%$ of cattle with poor, medium and good body condition, respectively. The majority of the infected animals manifest clinically poor body condition, as trypanosomosis is characterised by progressive weight loss (Radostits et al. 2007). Poor body condition is not only a result of trypanosomosis, and could therefore also result from other pathogens and nutritional stress.

As established earlier (Marcotty et al. 2008; Van den Bossche \& Rowlands 2001), this study also confirmed that the mean PCV of cattle with trypanosomosis is significantly lower than that of aparasitaemic animals. This finding is in agreement with various reports on local zebu from Ethiopia (Lemecha et al. 2006; Miruk et al. 2008; Stein et al. 2011; Tasew \& Duguma 2012). According to Van den Bossche and Rowlands (2001), reduction of $\mathrm{PCV}$ is an indicator of trypanosomosis.

The results of the current study indicate that three species of Glossina and other biting flies that serve as potential vectors for trypanosomes infest the settlement areas of the Hawa-Gelan district and hence can sustain the occurrences of trypanosomosis in cattle. Glossina pallidipes, G. morsitans submorsitans and G. fuscipes were the common species of Glossina identified, whilst Trypanosoma congolense is frequently detected, followed by T. brucei and T. vivax. The relative abundance of Glossina species caught and the prevalence of cattle trypanosomosis investigated could indicate a serious problem in the area. Therefore, progressive control methods aimed at reducing the Glossina species burden would be necessary to minimise the impact of trypanosomosis. Success of control options depends on active community participation. Therefore, mobilising the community and increasing their participation in control activity could play a key role in reducing the impact of the disease and increasing animal productivity.

\section{Acknowledgements Competing interests}

The authors declare that they have no financial or personal relationship(s) that may have inappropriately influenced them in writing this article.

\section{Authors' contributions}

K.L. (Haramaya University) and S.S. (Haramaya University) designed and led the project and were responsible for sample collection and laboratory analysis. J.B. (Hawassa University) and D.S. (Hawassa University) participated in designing the study, data analysis and writing the manuscript.

\section{References}

Abebe, G., 2005, 'Trypanosomosis in Ethiopia', Ethiopian Journal of Biological Science $4(1), 75-121$.

Abebe, G. \& Jobre, Y., 1996, 'Trypanosomiasis: A threat to cattle production in Ethiopia', Revue de Médecine Vétérinaire 147, 897-902.

Asha, A., Sheferaw, D., Wossene, A. \& Fekadu, A., 2008, 'Prevalence of bovine trypanosomosis and tsetse density in selected woredas of SNNPS, Ethiopia', Ethiopian Veterinary Journal 12(2), 131-139.

Bancha, B., 2001, 'Integration of tsetse survey data and agro-ecological characteristics from remotely sensed and field observations in a geographic information system in southern rift valley of Ethiopia', MSc thesis, Addis Ababa University and Freie Universität, Berlin. 
Bekele, J., Asmare, K., Abebe, G., Ayelet, G. \& Gelaye, E., 2010, 'Evaluation of deltamethrin applications in the control of tsetse and trypanosomosis in the
southern rift valley areas of Ethiopia', Veterinary Parasitology 168, 177-184. southern rift valley areas of Ethiopia', Veterin
http://dx.doi.org/10.1016/j.vetpar.2009.11.028

Bogale, B., Wodajo, K. \& Chanie, M., 2012, 'Occurrence and identification of bovine trypanosomosis in Genji district, western Ethiopia', Acta Parasitologica Globalis $3(3), 38-42$

Daya, T. \& Abebe, G., 2008, 'Seasonal dynamics of tsetse and trypanosomosis in selected sites of Ethiopia', Ethiopian Veterinary Journal 12, 77-98.

Desta, M., Menkir, S. \& Kebede, A., 2013, 'The study on tsetse fly (Glossina species) and their role in the trypanosome infection rate in Birbir Valley, Baro-Akobo rive system, western Ethiopia', Journal of Veterinary Medicine and Animal Health 5(7), 186-194.

Douglas, J.W. \& Wardrop, K.J., 2010, Schalm's Veterinary Hematology, 6th edn., Blackwell, Oxford.

Hawa-Gelan District Agricultural Office, 2009, Hawa-Gelan District Agricultural Office Annual Report, Rob Gebeya.

Leak, S.G.A., 1999, Tsetse biology and ecology: Their role in the epidemiology and control of trypanosomosis, CAB International, Wallingford, UK.

Lemecha, H., Mulatu, W., Hussein, I., Rege, E., Tekle, T., Abdicho, S. et al., 2006, 'Response of four indigenous cattle breeds to natural tsetse and trypanosomosis
challenge in the Ghibe valley of Ethiopia', Veterinary Parasitology 141, 165-176. http://dx.doi.org/10.1016/j.vetpar.2006.04.035

Marcotty, T., Simukoko, H., Berkvens, D., Vercruysse, J., Praet, N. \& Van Den Bossche P., 2008, 'Evaluating the use of packed cell volume as indicator of trypanosomal infections in cattle in eastern Zambia', Preventive Veterinary Medicine 87, 288300. http://dx.doi.org/10.1016/j.prevetmed.2008.05.002

Ministry of Agriculture (MOA), 1995, Ruminant livestock development strategy (RLDS), MOA, Addis Ababa.

Miruk, A., Hagos, A., Yacob, H.T., Asnake, F. \& Basu, A.K., 2008, 'Prevalence of bovine trypanosomosis and trypanocidal drug sensitivity studies on Trypanosoma congolense in Wolyta and Dawero zones of southern Ethiopia', Veterinary Parasitology 152, 141-147. http://dx.doi.org/10.1016/j.vetpar.2007.12.007

Mulaw, S., Addis, M. \& Fromisa, A., 2011, 'Study on the prevalence of major trypanosome affecting bovine on tsetse infested Asosa district of BenshagulGumuz Regional State, western Ethiopia', Global Veterinaria 7(4), 330-336.

Murray, M., Trail, J.C.M., Turner, D.A. \& Wissocq, Y., 1983, Livestock productivity and trypanotolerance, Network training manual, International Livestock Centre for Africa (ILCA), Addis Ababa.
Nicholson, M.J. \& Butterworth, M.H., 1986, A guide to condition scoring of Zebu cattle, International Livestock Centre for Africa (ILCA), Addis Ababa.

Pollock, J.N., 1982, Training manual for tsetse control personnel, Volume 2, FAO, Rome.

Radostits, O.M., Gay, C., Hinchcliff, K.W. \& Constable, P.D., 2007, Veterinary medicine: A textbook of diseases of cattle, sheep, goats, pigs and horses, 10th edn., Elsevier, London.

Regassa, F. \& Abebe, G., 2009, 'Current epidemiological situation of bovine trypanosomosis in Limu Shay tsetse controlled area of Upper Didessa Valley', Ethiopian Veterinary Journal 13(2), 19-23.

Rundassa, M.D., Menkir, S. \& Kebede, A., 2013, 'Prevalence and seasonal incidence of bovine trypanosomosis in Birbir valley, Baro-Akobo river system, Western Ethiopia', Journal of Veterinary Medicine and Animal Health 5(5), 138-143.

Stein, J., Ayalew, W., Rege, E., Mulatu, W., Lemecha, H., Tadesse, Y. et al., 2011, 'Trypanosomosis and phenotypic features of four indigenous cattle breeds in an Ethiopian field study', Veterinary Parasitology 178, 40-47. http://dx.doi. org/10.1016/j.vetpar.2010.12.025

Tasew, S. \& Duguma, R., 2012, 'Cattle anaemia and trypanosomosis in western Oromia State, Ethiopia', Revue de Médecine Vétérinaire 163(12), 581-588.

Taye, M., Belihu, K., Bekana, M. \& Sheferaw, D., 2012, 'Assessment of impacts of tsetse and trypanosomosis control measures on cattle herds' composition and performance in southern region, Ethiopia', Tropical Animal Health and Production 44, 1759-1763. http://dx.doi.org/10.1007/s11250-012-0134-0

Thrusfield, M., 2005, Veterinary epidemiology, 3rd edn., Blackwell Science, Oxford.

Tilahun, G., Balcha, F., Kassa, T., Birrie, H. \& Gemetchu, T., 1999, 'Tsetse and trypanosomiasis plot trial at Pawe settlement area, Tana Bales Valley, Metekel zone, Region 6, north-western Ethiopia', Proceedings of the 13th Annual Conference of the Ethiopian Veterinary Association, Addis Ababa, Ethiopia, 10-12 July 1999.

Uilenberg, G., 1998, A field guide for the diagnosis, treatment and prevention of African animal trypanosomosis, FAO, Rome.

Van den Bossche, P. \& Rowlands, G.J., 2001, 'The relationships between the parasitological prevalence of trypanosomal infection and herd average PCV', Acto Tropica 78, 163-170. http://dx.doi.org/10.1016/S0001-706X(00)00182-0

Vreysen, M.J.B., Mebrate, A., Menjeta, M., Bancha, B., Woldeyes, G., Musie, K. et al., 1999, 'The distribution and relative abundance of tsetse flies in the Southern Rift Valley of Ethiopia: Preliminary survey results', Proceedings of the 25th Meeting of the International Scientific Council for Trypanosomiasis Research and Control (ISCTRC), Mombasa, Kenya, OAU/STRC Publication No. 120, 27 September - 01 (ISCTRC), Mombasa, Kenya,
October 1999, pp. 202-213. 